\title{
Making Scientific objects and setting Standards: values, technology, government and the Enlightenment ${ }^{1}$
}

\author{
ANTONIO LAFUENTE \\ Instituto de Historia (CSIC) \\ antonio.lafuente@cchs.csic.es \\ NuRIa VALVERDE \\ Instituto de Historia (CSIC) \\ nvalverdep@gmail.com
}

Recibido: 15.06.2009

Aceptado: 02.11.2009

Governing is not the same as commanding. It is not sufficient to give orders from above, because the success of any action is linked to the level of personal involvement of the person carrying it out. Hence the importance of giving justification to an action. But we know this is not enough. Or rather, justification is only effective if it is based on identifiable activities and objective facts. This is easy to say, but increasingly difficult to understand. For the Moderns, however it was (and perhaps still is) quite clear. According to them it was sufficient to make sure that our information fulfilled certain conditions: among other things, it was crucial that it be obtained by means of specialized machines, which would avoid, as far as possible, the subjectivity and disarray of our senses. It was necessary to convert the greater or lesser intensity with which we detect phenomena into numbers and calculations.

Instruments, then, had a decisive function: by acting as mediators between the body and the world they not only converted the syntax of words into an algebra of numbers, but they moulded our surroundings according to whatever could be quantified. The sky was no longer the realm of the gods and other mysteries, but became the space of the stars and meteors, where atmosphere turned

${ }^{1}$ El artículo parte del proyecto I+D+I: «Redes, escalas y visualización de objetos científicos en la Europa Moderna, ss. XVII-XIX», financiado por el Ministerio de Ciencia e Innovación. Ref: HAR2008-05042.

EMPIRIA. Revista de Metodología de Ciencias Sociales. N. ${ }^{\circ}$ 18, julio-diciembre, 2009, pp. 115-146. ISSN: 1139-5737 
into air: a compound which could be defined in chemical, optical and climatological terms and which, as a result, could be treated as an experimental object, whether to study combustion or to correct the observations of refraction. Land, too, could now be contained within this new classification, which contained a special type of object: maps of geodetic precision, tables of demographic statistics, or biogeographical charts of the distribution of vegetable resources. Taken all together, these objects to which we refer reconfigure the world in a double sense: on one hand, they divide it into quantifiable experimental objects and, on the other, they convert it into a subject which can be represented and administered. Facts (entities newly born from the interaction between us and our machines) become confused with nature. Thus they become a profoundly political business, because since their arrival on the stage of public life, it would be very important who possessed the instruments and was able to manipulate them between the two idioms, from academic to public, between the old and the new ${ }^{2}$.

In the Enlightenment the truth was no longer a metaphysical entity, but became, according to Lorraine Daston, a social and material practice which aspired to be what Rorty described as a thing whose only obligation was to offer «...the most useful description for our purposes» (Baker \& Raill, 2001, p. 27). If Rorty and Daston were right, the idea that science is a subject of experts, even away from their environment, is an insensitive oversimplification of the impact which the public and the salons acquired during the eighteenth century; remember that innumerable historians see Enlightenment culture as the manifestation of a great public conversation. On the other hand, scientific instruments do not operate like fishing nets, but as in archery they demand great physical discipline from their practitioners, and from the institutions a host of conventions about where to place the target and how to measure the distance between the arrow and the bullseye.

Not only did the world of science expand from the monastery to the city, but it also had to achieve a practically planetary scale. The 1791 edition of the Diccionario de Autoridades includes a definition of the Spanish word estado («state») as the «summary in general terms resulting from detailed relations which are normally set down on paper». And although earlier editions connected the term with the idea of measurement, none of them was able to show

2 This was the principal argument of Bruno Latour's (1993) well-known We have never been modern, a text which classifies as miraculous (and unjustified) the sudden irruption of facts into our culture, newly-minted entities used as a test-bed for discrepancies, and the foundation of political coexistence. Indeed, conceding the status of a fact to something is (was) far from trivial, and could have very serious public repercussions. Hence some historians have taken great care to analyse the lives of those who best personify our ideals of wisdom and thoroughness, in order to discover how they were able to endow their ideas with so much authority. And, of course, the studies that Mario Biagoli, Steven Shapin, Simon Schaffer or Peter Galison have made of the historiographic legends represented by Galileo, Boyle, Newton and Einstein, leave no room for doubt; and, in our opinion, they have shown that it is useless to try to differentiate between experimental conventions, institutional rhetoric and cultural practices. See Biagioli (1994), Shapin \& Schaffer (1985), Shaffer (1989), Galison (2003).

EMPIRIA. Revista de Metodología de Ciencias Sociales. N. ${ }^{\circ}$ 18, julio-diciembre, 2009, pp. 115-146. ISSN: $1139-5737$ 
with such clarity the link between papers, charts, thoroughness and bureaucracy. It seems clear that from then onwards the emergence of the state implied detailed quantification and, in consequence, floods of grey literature, hosts of pen-pushers and algebraists, as well as a hierarchical structure calling for increasing levels of abstraction (or summaries) as descriptions rose up the pyramid of command $^{3}$. Because, in short, the state of a thing was always the same as the situation it was in. And since the times of Galileo the state of a moving object, of a changing entity, has been defined by the value which we assign to the parameters measuring its evolution in time. Hence, and this is a novelty which the Enlightenment brought about, the state is less and less like a painting and more and more like a set of tables.

All of the eighteenth century economists were aware of this, because they were all taught to think about the wealth of the kingdom in terms of a balance of payments. To govern is to quantify, but also to set standards. This idea was rarely expressed more forcefully than by Miguel Antonio de la Gándara, author of the influential Apuntes sobre el bien y el mal de España (1759) [Notes on the good and ill of Spain], who recommended the final solution for the ills of his country or, rather, of the Spanish Crown, which should be based on «one currency, one law, one system of weights, one of measures, one language and one religion». In other words, there needed to be one mega-office of standards (or, as we would say nowadays, for planning). And so it was important do away with individual quirks, to set up an approval authority, to prepare patterns and an educational system in order to impose them. In short, what Gándara had in mind was the bureaucratic utopia of the state.

What we are going to do is to explore how science became a toolbox for the rationalisation of the monarchy: that is, of the government of the people and of its territories ${ }^{4}$. Such a statement would hardly be very original if it meant only that science was used for political purposes. Our thesis here is that scientific objects were transformed into the very stuff which was to be governed: a tendency driven by the new ways of producing, validating and managing the information needed for government issues, and which Foucault called gouvermentalité. It would be a mistake to imagine that these processes obeyed any preconceived plan proceeding from an office or laboratory. Everything was more fortuitous, even though any state of affairs might lead to a conjunction, and produce the conviction that the cult of conventions and their paraphernalia was what united surgeons, botanists, engineers, astronomers and geographers. Moreover, the

3 As Theodore Porter points out, the problem of quantitative objectivity is to generate reliable public knowledge, in clear contrast to the privacy of the experiment. The need for it stems less from scientific necessity than from political requirements (Porter, 1995, pp. 229-230).

${ }^{4}$ We have made a first approach to the process of territorial rationalisation and its links to botany in Lafuente \& Valverde (2004), pp. 134-147. Recently we have also expanded our reflection on the political meaning of the different kind of information shown (and hidden) on imperial maps in Valverde \& Lafuente (2009), pp. 198-215.

EMPIRIA. Revista de Metodología de Ciencias Sociales. N. ${ }^{\circ}$ 18, julio-diciembre, 2009, pp. 115-146. ISSN: 1139-5737 
certainty of this fact expanded within the political arena of the court, going so far as to make the tasks of governance and management practically indistinguishable: a shift with wide-ranging effects, since for a manager problems are intractable until they are turned into defined, measurable and classified objects. Choosing the best possible alternative was to select the best informed choice, and this tended to coincide with the one most refined by instruments and figures. So the Enlightenment engendered a new relationship of closeness between the men of learning (technical) and the people in power (bureaucratic). Because if anyone knew about numbers and tables it was those people who put the heavens in almanacs, the Empire on a map, plants in a system and wealth on a graph. Nobody like the scientists had dreamt so much of disciplines, instruments and formulas. Nor had anybody shown such an overwhelming passion for translating all problems into symptoms, signs and numbers. And so it was that the state became a scientific question, and science became a matter of state. And now we can look at some details.

\section{THE FABRICATION OF THE VALUES OF STANDARDIZATION}

Let us pause to analyze the changing values implied by the introduction of scientific artefacts. During the eighteenth century their importance grew continually: at first they were no more than an occasional passing literary reference, but then they came to support the conviction that nothing better defined scientific activity than the detailed knowledge of instrumentation and its effects (Valverde, 2007). And it is a fact that practical experiments - that is, observation by instruments - were the principal means of establishing connections between social values and cognitive values. Every time that anybody picked up a magnifying glass, a watch or a thermometer he was not only experimenting with nature but also with culture, for it was during the Enlightenment that the shift took place from accurate knowledge to precise knowledge, which is now considered modern.

Spain, like other countries, took part in the process of interchange of knowledge on a European scale. As a result it had to have at its disposal the necessary instruments to participate in any international campaign of correspondent observations. For we already know what happens in science: the laws of Newton, for example, are valid everywhere (they are universal) so long as we have the necessary scientific equipment wherever we wish to check them. So any country who wished to get involved in the undertaking of knowledge had to begin by acquiring instruments to gather data. Then it would have to expand scientific training or, in other words, experimental teaching; for, of course, science deals with artificial facts produced in laboratories. And finally our hypothetical country would have to update its language ${ }^{5}$, that is, to favour a culture which was fa-

${ }^{5}$ On the effort made to translate into Spanish, as well as the introduction of the paradigms and authors characteristic of modern science in Spain, see Lafuente, Puig-Samper, et al. (1996), pp. 965-1028.

EMPIRIA. Revista de Metodología de Ciencias Sociales. N. ${ }^{\circ}$ 18, julio-diciembre, 2009, pp. 115-146. ISSN: $1139-5737$ 
miliar with the new scientific objects and the words which identified or mobilised them. This was a task which, as well as schools, called for the involvement of other agents of social change such as the press, private societies or museums ${ }^{6}$.

In Spain these changes began with sufficient force from the time of the second reign of Philip V, and the information at our disposal shows that the process was very soon consolidated during the reign of Fernando $\mathrm{VI}^{7}$. It was about that time that scientific instruments began to invade many areas in which they had hitherto been unknown: among these, we may highlight the press, academies, craftsmen's workshops and, of course, private salons and cabinets ${ }^{8}$. In general terms, we may say that the instrumentation which was acquired at that time was for the use of geographers and astronomers and, as such, consisted of machines of an apparently passive nature, in the sense that they merely registered positions and properties (distances, variations and intensities) without interacting in any way with nature. Consequently they were trusted, because they created a transparent, unquestionable link between the object at which they were aimed (or which they measured) and the figure obtained. A large part of their reliability depended on the reputation of their creator. If the maker had a good reputation, the instruments were seen as neutral, which meant that nobody could question whether they could fail or provoke errors. Instruments appeared to possess their own mysterious aura for, as the publicity produced by the craftsmen claimed, the precision of calibration increased constantly, from the 15" in 1700 and 8" in 1725 to the admirable 1" or 2" attributed to John Bird's quadrants fitted with micrometers.

We do, however, know that many of these technical boasts did not have an immediate scientific connection. Indeed, since there is always a great deal of difference between the theoretical possibilities of an instrument and the real probability that they can be achieved by an observer, the use of a high precision instrument was more a guarantee of its rhetorical relevance than of its experimental

${ }^{6}$ On these subjects the two most complete monographs are probably L. Stewart (1992) and Golinski (1992). For Spain, Lafuente \& Pimentel (2002), pp. 111-155. See also Rousseau (1990), pp. 147-224; Bensaude-Vincent (2000); Secord (2002), pp. 28-57; Cooter \& Pumfrey (1994); pp. 237-267. And, concerning the American world, Sheet-Pyenson (1988).

7 See Lafuente \& Peset (1982), pp. 193-209; Lafuente and Peset (1981), pp. 233-262; Lafuente (1991), pp. 157-167; Lafuente (1992), pp. 91-118.

8 The historiography of Spain, unlike that of Britain or France, is hardly overflowing with information confirming this transition; but we do have indications that in Spain, Portugal and Naples the experimental culture also had the support of public opinion. And the foundation of new institutions such as observatories, gardens and expeditions was surrounded by rhetoric entrusting the success of the undertakings to the costly equipment acquired for them. This explains why more than 600.000 reales were invested in the instruments for the Observatory of the Colegio Imperial (1750) and those which were destined for the Casa de la Geografía (1752). In any case, as well as the reports of the institutions of the time, literature and the press, we can consult books such as Moral (1998), or Lesen y Moreno (1863), which offer interesting facts about the movement of objects and information within the milieu of the Economic Society of Madrid.

EMPIRIA. Revista de Metodología de Ciencias Sociales. N. ${ }^{o}$ 18, julio-diciembre, 2009, pp. 115-146. ISSN: $1139-5737$ 
potential ${ }^{9}$. Since they were also rare, their use was not really necessary since, as was said at the time, the «necessary degree of accuracy» did not require such high levels of precision. In these cases, there was a clearly visible discrepancy between precision as a myth and precision as a challenge or, in other words, between the rules for the production of knowledge and the practical likelihood of fulfilling them. In the end, as we shall see, the obsession with reliable data shifted towards the establishment of confirmed conventions, a change that reflected the growing political maturity of scientists; yet it in no way minimizes the amazing reputation of the instrument as a symbol of technical progress.

The comprehension of the instrument itself frequently became the main motive for its use, since nobody was absolutely clear what was being measured or how accurate the figures obtained needed to be. We all know that a barometer measures the relationship between height and pressure, so long as the scale is accurately set at zero and the divisions on the tube are marked equidistantly. And besides, the point was that it was not very clear at the time what pressure actually was or, in other words, it was not known with what other variables (such as temperature for example) the rise of the mercury was related ${ }^{10}$. So the correct use of an instrument involved the theory of the phenomenon and the theory of the instrument, as well as the perfection of a series of craftsmen's precision techniques, the mastery of which called for considerable experience and specific tools which had to be manufactured ad hoc. And finally, instruments are like chains, for they both have the strength (or value) of their weakest link. So now it is easy to understand why such importance should be assigned to instruments, since their arrival on the scene not only reveals the development of sophisticated tools and precision technology, but is the best indication that great theoretical breakthroughs and productive interdisciplinary connections are being made.

The purpose of systematic - for example, thermo-barometric or astronomical - observations was to establish regularities. Anyone who ventured a theory correlating two phenomena had, in the first place, to invent a machine to quantify the relative variations and, second, to convince others to acquire the same device. Then, after comparing the figures of different correspondent observers, he had to find out whether the phenomenon was local (such as gravitational variations in the presence of large mountainous masses), regional (such as the existence of micro-climates favouring a specific illness or a particular composition of tannins), national (such as the more or less choleric or phlegmatic personality of Spaniards compared to the English) or planetary (such as the relationship between the phases of the Moon and the tides). And, of course, when one begins to discuss data, inevitably the question arises as to whether they are comparable: in other words, whether the instruments with which they have been collected are matched. It is not merely a matter of collecting the same type of data, but the lo-

\footnotetext{
9 See Bennett (1989), pp. 105-114.

${ }^{10}$ It was still believed in the middle of the eighteenth century that temperature did not affect the barometer. See Middleton (1964), pp. 176-177.
}

EMPIRIA. Revista de Metodología de Ciencias Sociales. N. ${ }^{o}$ 18, julio-diciembre, 2009, pp. 115-146. ISSN: 1139-5737 
cations must be equivalent, the system of collection agreed, the codes in which to express them standardised, and the instruments interchangeable. In short, our point is clear: the use of instruments leads to standardisation, and calls for rules which must be observed. An instrument contains a good deal of science and technology, but it is the symbol of a wish for order and accuracy, the maximum expression of a new moral economy (Daston, 1995, pp. 3-24). Instruments, after all, provoke the existence of collaborative structures and organizations whose aim is to regulate; for measuring equipment is useless unless there are certain common areas of exchange, and unless such exchanges are made according to some agreed standards.

Hence the Academies' insistence on giving instructions on how to make observations. But this objective of unifying activities and inscriptions presented certain problems. At the beginning of the century experimental philosophers were mindful of science's commitment to reproducibility. Scientists produce wonders, but they are not magicians. They are respectable, not only because they have renounced secrecy and have adopted the public realm, but because everything they do can be reproduced, and can be repeated by anyone who has the same instruments. The key, then, lies in discipline and technology. That is, in the wish for standardisation and in the capacity for cultural adaptation. As science distanced itself from the cult of the exceptional, it became necessary to think of the universal as constant, and to define the identity of an object as a function of the regularity of its behaviour when subject to tests, irrespective of where they were carried out. The notion of reproducibility came closer to that of validity ${ }^{11}$.

Instruments were bought for their usefulness. What we mean is that not only were they shown to be useful in the processes of the territorial organisation of the Empire, but that they also had great political and social prestige.

The ministers of Charles III's court did not deny their economic usefulness, and neither shall we. In 1788 the organisation of the Malaspina Expedition called for a political examination of the question of scientific rigour. The organizers behaved according to a simple formula: good policies demand the best data and, therefore, the most precise instruments. That is, a new highway was created linking accuracy with usefulness. The equation was solved as was right and proper: by buying an exceptional collection of fine instruments. Jacinto de Magallanes (1732-1790) was the agent charged by the Spanish Crown with buying them in London. The inventory of what they took to America makes exciting reading. Anyone familiar with the history of scientific instruments will approve the fact that the astronomical pendulum was by Graham, the two achromatic glasses were by Dollond, or that two quadrants came from Sisson's workshop and the other from Ramsden's. And since Berthoud was unable to supply enough, three of John Arnold's chronometers (61, 71 y 72) were included ${ }^{12}$.

\footnotetext{
11 See Licoppe (1996), pp. 117-124 ; Park (2000), pp. 77-89; Park \& Daston (1998).

12 On these instruments, see Lafuente \& Sellés (1988), pp. 330-333; Glick (1989), pp. 49-65; Pimentel (1998).
}

EMPIRIA. Revista de Metodología de Ciencias Sociales. N. ${ }^{\circ}$ 18, julio-diciembre, 2009, pp. 115-146. ISSN: $1139-5737$ 
The requirement to produce precision was as much scientific as political, since as L. Daston and T. Porter point out, the form in which the instruments are used (that is, the rules, the tables and the specialist terminology we use to express results) also has its effect on observers ${ }^{13}$. Indeed, nobody could consider himself an active member in a network of observations without accepting that he must regularize his experiences, including rules on how to read other people's documentation and how to prepare his own reports. As we know, in science the rules of style have to be observed. All members of the network require transparency in the description of any movement obtained in the laboratory, for without clarity there is no reproducibility and thus precision ceases to be a public right. Without style, therefore, there is no morality. What is more, without instruments our civilization would be cast adrift.

Of course. Once it has been decided to involve instruments in our controversies, endowing the figures they produce with precision, and more importantly, with permanence, unless changed by more data and other tools, we can never renounce that drift towards civilization. And there is an exceptional case to corroborate what we have been saying: the Franco-Spanish expedition to the Viceroyalty of Peru.

\section{THE SPIRAL OF SCIENCE}

The dispute over the shape of the Earth was one of the most compelling scientific controversies of the eighteenth century (Lafuente and Mazuecos, 1989) ${ }^{14}$. And indeed, the involvement of several expeditionary groups from different countries called for very important consensus on the units in which measurements should be expressed, as well as to establish precise guidelines on how to construct precision instruments. It is well-known that the arguments had caused confrontations between the Royal Society and the Academie des Sciences, which finally provoked important disagreements between the English and French scientific communities ${ }^{15}$. And so it was that the dispute finally became very public, and its solution somewhat urgent.

In order to bring the dispute to an end it would suffice to determine the value of one degree of meridian at two different latitudes, and to compare their measurement. If they were both the same, the Earth would be spherical; if, on the other hand, they were different it would be possible to discover which axis was

\footnotetext{
13 See Daston (1999), pp. 78-100; Porter (1995); Knorr-Cetina (1999).

14 There is an unpublished English version of this book in the CSIC's repository: see http://digital.csic.es/handle/10261/15737; Lafuente and Delgado (1984)

15 This section is based on the following works: Lafuente and Peset (1984), pp. 235-254; Lafuente (1995), pp. 125-140. The more nationalistic connotations of this controversy have been dealt with in greater detail in the second chapter of Lafuente \& Mazuecos (1989). There is an English version of this chapter under the title of «London and Paris: two sciences of the Earth»; see http://digital.csic.es/bitstream/10261/15737/4/Gentlemen_of_the_Fixed_Point_Chapter_2.pdf
}

EMPIRIA. Revista de Metodología de Ciencias Sociales. N. ${ }^{o}$ 18, julio-diciembre, 2009, pp. 115-146. ISSN: 1139-5737 
shorter, as well as its magnitude. From the cabinet it seemed quite simple: it was said that it would be sufficient to organise two expeditions to two latitudes as far away from each other as possible, in order to accentuate the expected difference in the two measurements of the degree. And this, or so they thought, is what was done: one expedition would go to Lapland under the direction of Maupertuis; and the other to what is now Ecuador, then forming part of the viceroyalty of Peru ${ }^{16}$.

The mission of the expedition to America consisted of two widely different stages: the geodetic stage, then called geometric, consisted in triangulating a distance of some 400 kilometres along the inter-Andine corridor, taking advantage of the peaks of the eastern and western mountain ranges to install their observation posts ${ }^{17}$. During this stage, which took place between 1736 and 1739 , they had to face two types of problem in order to assure themselves of the correctness of the final result: on the one hand, problems arising from the scientific equipment they used, especially the quadrant and the barometer; and on the other, those arising from the host of extra verifications and complimentary observations whose objective was to purge the date of foreseeable errors and to reduce the sides of the triangulation to sea level.

The second phase dealt with the astronomical observations to determine the angle of the triangulated arc. This operation took them almost four years, because the astronomical instrument arrived broken in Quito after the gruelling climb on the backs of mules. That being the case, the academics had to busy themselves in the construction, calibration and installation of a great astronomical quadrant of eighteen foot radius, which would replace the one they brought from Paris. By and large, once these operations had been carried out, it was an observation programme which in theory was easy to do. In fact, its practical execution had been carried out rapidly and convincingly by the expedition to the North, those who were working in Lapland. So why the delay, what happened in Peru?

Undoubtedly, when the expeditionaries learnt that the Lapland commission had been completed in 1738, in only one year and giving conclusive results in favour of the theory of polar flattening, it was a salutary lesson and stimulated the design of an experiment which sought levels of precision hitherto unknown; the American expeditionaries thought that if history was not going to remember them for confirming Newton's views in the controversy, it would have to reserve them a space to commemorate the vast and meticulous programme of observations they were now ready to carry out .

${ }^{16}$ It was headed by the Frenchman L. Godin assisted, among others, by Charles-Marie de la Condamine, Pierre Bouguer, Joseph Jussieu, as well as the two Spanish Marine officers Jorge Juan and Antonio de Ulloa, and the scholar from Quito, Pedro Vicente Maldonado. See Lafuente \& Estrella (1985); Zúñiga (1977).

17 The distance, equivalent to more than $3^{\circ}$ of latitude, was sufficient for the proposed purpose, and measurements of the check base, obtained as required using two independent methods, confirmed that the error was almost negligible.

EMPIRIA. Revista de Metodología de Ciencias Sociales. N. ${ }^{o}$ 18, julio-diciembre, 2009, pp. 115-146. ISSN: $1139-5737$ 
In principle, their concern for the precision of their measurements was praiseworthy. This attitude led them to carry out systematic programmes of research of natural phenomena about which there existed absolutely no agreed theory, nor sufficient accumulated experience. These were questions, rather marginal if you will, but on the frontier of scientific knowledge, and particularly of physics or mechanics. Among them were subjects such as atmospheric and astronomical refraction, local variations in gravity and, therefore, of the verticality of the plumb line in the presence of large mountainous masses, the barometric measurement of altitude, the expansion of materials, the construction of instruments and the engraving of scales, etc.

The expedition members, in search of glory, were not prepared to spare any effort; the circumstances which were so often on the point of ruining the mission would oblige them to face difficulties unheard of for science of the time. A simple mention of some of them will clearly demonstrate this; for example, systematic astronomical observations had never before been made at an altitude of over 3000 metres; and the length of the sides of the triangles, the difference in height between the benchmarks and variations in temperature had hardly ever been so great. Similarly, it was not normal to carry precision instruments practically of laboratory standard - across high mountain peaks and through long and arduous treks, which caused serious maladjustments in the zenith sector or the barometer ${ }^{18}$. The combination of all these factors cast a permanent shadow of doubt on the quality of the measurements, since it was, besides, very difficult to decide whether errors were attributable to deficiencies in the observer, to the faulty construction of the instrument, or whether they were the effect of one of the physical phenomena mentioned, which were little known at the time. In addition, among the proliferation of partial experiments and conflicting figures, there existed no clear criteria to differentiate between theoretical predictions, observational practices and the real expectations of accuracy which were to be hoped for from the group of operations as a whole. In short, they were facing problems which overwhelmed the objective of their mission, without sufficient conceptual instruments, or the necessary scientific equipment. The academic undertaking, then, slowly became an adventure whose scientific, political, social or biographical implications were to become intermingled, so that none of them would overshadow the others ${ }^{19}$. We shall not spend any more time on consider-

18 The manufacture of scientific instruments in those days was the work of craftsmen, where each constructor had his own methods for the layout of the scale, the fixing of the zero, or achieving verticality. It was therefore very far from the ideal standard, for example, which would ensure the comparability of measurements. On this problem, see Daumas (1953); Turner, A. (1987) ; Turner, G. L'E. (1990), and Turner G. L'E. (1976), pp. 173-182.

19 The risky nature of this adventure had already been suspected before Godin proposed the measurement of one degree of the Meridian near the Earth's equator, in the last academic session of 1733. La Condamine's earlier proposals to carry out the work in the Portuguese colonies in Africa or Brazil had been rejected for fear of unknown dangers; before leaving Paris, Fouchy, Pimodan and de la Grive, less in need of glory, renounced their participation in a journey whose hardships

EMPIRIA. Revista de Metodología de Ciencias Sociales. N. ${ }^{\circ}$ 18, julio-diciembre, 2009, pp. 115-146. ISSN: $1139-5737$ 
ations of the difficult conditions of life on the plateaus of the Andes, nor of the continuous sufferings and misunderstandings to which the expedition members were subjected. The account of their vicissitudes would oblige us to make this section unnecessarily long ${ }^{20}$. Let us therefore take it as read and pass on to some of the scientific aspects of the mission. In this respect, for reasons of

everyone could foresee. When they arrived in Quito in May 1736 financial resources were so scarce that they had to go into debt, rather than have to pay for their own work. Moreover, they were still sailing across the South Seas bound for Guayaquil when La Condamine and Bouguer, after bitter arguments with Godin, decided to break away from the expedition and to continue their journey by another route to Quito. The tension among the members of the expedition, although sometimes beneath the surface, would never disappear, and nor would the reasons which fuelled the confrontation. And if the internal fights were bitter, the struggles with the colonial Administration were no less so. The Kingdom of Quito was plunged into a deep crisis, which at that moment was worsened by the recrudescence of the old struggle between the two dominant ethnic castes, the chapetones (new arrivals from Europe) and the Creoles (the long-established European settlers). The low yield of mercury from Huencavélica had killed off silver mining, and had notably reduced the internal American demand for manufactured products, thus initiating the process of colonial economic regionalisation, much encouraged by the systematic introduction of foreign goods and particularly serious in the textile sector. Spaniards and Creoles looked on the situation with great concern, and were both aware of the problem and jealous of their respective commitment to the judicial order. All of this, as we know, affected the life of the academics. While on the one hand they were able to take advantage of the confusion to obtain ready financial resources, on the other they were firmly in the sights of the local authorities as scapegoats. Actually, there is no definite proof about the supposed commercial practices of La Condamine, although it is true that he did face two legal hearings, to which must be added those provoked by the murder of the expedition's surgeon Senièrgues during the riots against the chapetones which broke out in the city of Cuenca to cries of «Long live the King, and death to the gabachos (French) and bad government». For more on this, consult Ramos (1985), and Molina (1992), Guillén (1973); José P. Merino Navarro and Miguel M. Rodriguez San Vicente, have published a facsimile edition of the Observaciones astronómicas... and the Relación histórica del viaje a la América meridional..., the two works written by Juan and Ulloa about their scientific work. Also, Lafuente (1983), pp. 549-629.. There is a novel which has paid particular attention to these aspects, F. Trystram, Le procès des étoiles, Paris, Seghers, 1979.

20 The hardships they had to face were considerable. So much so that their activities were the object of controversial commentaries from the inhabitants of the country. The following testimony of Ulloa could not be more eloquent, nor more entertaining: "Now it is reasonable to consider what diversity of opinions would be formed in those villages by their inhabitants: on the one hand, they were amazed by our resolution; on the other, surprised by our perseverance; and finally, all was confusion, even among the most educated; they asked the Indians what sort of life we led in those places, and were appalled by the report they gave: they saw that they all refused to assist us, although robust in nature, tough and used to hardship; they observed the peace of mind with which we lived for an indefinite time in those places; and the resignation with which, having completed our allotted time of work and solitude in one place, we went on to others: and in such wonderment and novelty, they did not know to what to attribute it. Some thought our resolutions madness; others opted for greed, believing that we were looking for precious minerals by means of some particular method we had invented; others held us to be Magicians, and all were engrossed in endless confusion, because in no case that their thoughts conceived, could they have found any achievement worth the fatigue and hardships of this life: a matter which still keeps most of those people in doubt, unable to persuade themselves of what is the true purpose of our voyage, as ignorant of its significance»; Juan and Ulloa (1748).

EMPIRIA. Revista de Metodología de Ciencias Sociales. N. ${ }^{o}$ 18, julio-diciembre, 2009, pp. 115-146. ISSN: 1139-5737 
brevity, we shall spend time only on the problem of barometric levelling and that of the construction and installation of the great astronomical sector.

As in all the cases studied, the expeditionaries did not arrive completely unequipped in Quito. Mariotte's theory gave a theoretical model from which to make an accurate reading of the variations of a column of mercury ${ }^{21}$. However, their first readings not only presented a considerable diversity of results, but a worrying dispersion, which put into question the correctness of the model and the viability of the mathematical law normally employed. And, after much hesitation, they concluded that this assertion must arise from one or more of the following three causes: a maladjustment or manufacturing fault in the instrument; errors in the marking of the tube which, from past experience, appeared to be more significant when the difference in heights to be compared was not very great; and, finally, that they were applying a mistaken theory. Surprisingly enough, the expedition members agreed that what was in error was Mariotte's hypothesis, a theory that according to their data was only valid when height differences were considerable. This change of course, obviously, implied a reaffirmation of their faith in the instruments and in the measuring conventions ${ }^{22}$, a novelty which is worth emphasising since no one knew better than the expeditionaries the difficulty of ensuring that the instrument was firstly properly made and, secondly, properly used.

The results were disappointing. In absolute terms they could fluctuate by as much as 700 toises, which meant an error of $35 \%$ in the average value given to the height of a location ${ }^{23}$. And although this appears to be a high figure, it was

${ }^{21}$ We have gone into these matters in great detail in the already cited Lafuente \& Delgado (1984). On the adaptation of the barometer as a scientific instrument, see Middleton (1964). J. A. De Luc's report Recherches sur les Modifications de l'Atmosphère (Geneva, 1749) contains interesting historical references.

22 Juan and Ulloa explained the abandonment of Mariotte's theory, because «... at distances close to the Earth's surface there is said dilatation [of the air] in another different ratio [than the geometric] and [the observations] imply that the layers, or strata of equal weight, into which the atmosphere which was thought to be divided, dilate in arithmetic progression, each of them corresponding to an equal increase or decrease in the height of mercury in the barometer», See Observaciones..., p. 126. Bouguer attributed it to the fact that «... the elastic forces of the air do not follow the inverse ratio of expansion [...] the second law of M. Mariotte which assumes the same elasticity in all parts of the atmosphere is by default inaccurate at the top of the mountains». The text comes from a letter from Bouguer to Du Fay (Petit Gôave, 25.X.1735), Archives de l'Observatoire de Paris, ms. C-2-7.

23 This explains Bouguer's interest in undertaking geodetic levelling, a method which in our opinion would probably not have obtained more accurate results, as its implementation would require an additional triangulation crossing the western Andes and the unexplored jungles of the region of Esmeraldas, the only way to connect the coastal plain geodetically with the interior highlands. It also explains Godin's radical opposition to a new undertaking that would delay the progress of work without giving much hope of significant benefits: for a variation of 200 toises in determining the height of a signal would only have an effect of 2 toises of error on the final measurement of the degree, and even that would assume the absence of that great ally of surveyors: that is, the almost always favourable compensating error.

EMPIRIA. Revista de Metodología de Ciencias Sociales. N. ${ }^{o}$ 18, julio-diciembre, 2009, pp. 115-146. ISSN: 1139-5737 
high only in relative terms; we know, as they did, that the influence on the final result would be negligible. And if they already knew the limited effect of errors on levelling, why did they spend so much time on observations and allow the internal argument to lead to a severe communication breakdown between the two groups? The academics had a radical commitment to the practices and resources of empirical research, as well as a tendency to worry about problems which, while not to be underestimated, were not significant for the primary objective of the mission. At that time, however, things were not as clear as we see them today, and it is perfectly plausible that they also considered this to be science: this coming and going with instruments, logging data and taking extreme care in the observation of phenomena that should have been considered as negligible. Today we know that such behaviour can only lead to wasted time and an increased number of errors. Anyway, the case in question illustrates the ever-complex relationship between a collection of more or less accurate observations and a conclusive experiment. Careful reading of the manuscripts - especially the letters they exchanged and their notebooks - enables us to make further progress in our comments.

Scholars, as well as being scientists involved in a mission, were normal people full of doubts and eager to convince. One of the most commonly used ploys was to present themselves as hardworking people, indifferent to discouragement and overwhelmed by huge masses of data and calculations: mathematics and observation, rather than being used to support a thesis, were skilfully presented in a way that would simulate experimental exuberance and dull the critical capacity of the reader. The latter would be defenceless before the tumult of equations, corrections, instrumental precision and complaints about the hostility of the territory and its inhabitants. Many are the testimonies that endorse this assertion; suffice it here to repeat the bitter reproach that La Condamine sent to Bouguer in 1746, acknowledging his painful discovery that accuracy was only a compromise between the means available and the audience, between theoretical objectives and permitted practice: «I have concluded [La Condamine wrote] that all calculation cannot be done rigorously, but by approximation [...] You explain yourself enigmatically, and no doubt intentionally. I am sure that it is wrong to oblige those in whom calculation produces fever to calculate and recalculate, without mercy and without end, without ever retracing their steps and going back to the cause of the errors of calculation, without making another mistake and making checks, which are often a new source of error and make me waste ten times as much time as if, being less punctilious, I had renounced these incidental and ancillary investigations ${ }^{24}$. This complaint reveals a sort of «consolation prize»: the via crucis the scientist must follow in his search for truth undoubtedly confers on him the authority of the ancient prophets and of the new pioneers.

${ }^{24}$ Letter from La Condamine to Bouguer (Deniecourt, 17.X.1746), Archives de l'Observatoire de Paris, ms. C-2-7, pp. 10-11. See, Lafuente \& Mazuecos (1989), pp. 176s.

EMPIRIA. Revista de Metodología de Ciencias Sociales. N. ${ }^{\circ}$ 18, julio-diciembre, 2009, pp. 115-146. ISSN: 1139-5737 
After the geodetic phase of the mission began the second stage, the determination of the extent of the arc by observations of latitude. In late 1739, however, the malfunctioning of the instruments put them in a desperate situation. Different observers, in different places, and after a series of observations, found results whose average error of about 30" was so great that the entire mission seemed doomed to failure ${ }^{25}$. They were convinced in this case that it was essential to rebuild the instrument ${ }^{26}$. The decision was undoubtedly one of the most awkward the team ever took. The reason is obvious: even if their experience as observers was considerable, they now had to face a set of problems that not even the finest specialized European craftsmen could settle satisfactorily. Not only were the technical problems to be resolved of extraordinary complexity, but there would be a very substantial hold-up in their operations.

The idea of a hasty return to Paris was unthinkable. It was thus vital to rebuild the instrument, but their enormous effort was not rewarded by the expected results. Repeated check observations showed that dispersion varied between 20 and 30 seconds, an excessive margin of error which required further verification and more corrections to the instrument. They finally made such fine adjustments and reconsidered so many little details that the obstinacy with which new divergences reappeared was attributed to the existence of movement of the stars themselves ${ }^{27}$. This was a hypothesis which, had it been confirmed, would have meant a discovery of great theoretical and practical reper-

${ }^{25}$ After the geodetic phase of the mission, the scholars were divided into two groups to determine the latitude of the two ends of the triangulated meridian: Godin, Juan and Ulloa made their observations in Mira and Cuenca ( $\left.3^{\circ} 27^{\prime}\right)$, while Bouguer and La Condamine chose Tarqui and Cochesqui ( $\left.3^{\circ} 7^{\prime}\right)$. Each group performed its work between late 1739 and early 1740 . The whole program of observations seemed to be finished, when Godin, in April 1740, observed serious differences in their measurements and decided to start again. From then onwards, amid a host of questions and new internal disputes, there began the verification observations, which continued until mid-1742, the date from which they finally proceeded to the determination of the extent of the arc of the meridian. In short, four years to determine the latitude of two points is an excessive amount of time that can only be justified by taking into account the enormous number of difficulties that faced the team. The details are discussed in Lafuente y Delgado (1984), pp. 209s.

${ }^{26}$ Indeed, the 12-foot sector had suffered serious damage due to constant and arduous moving around. Bouguer acknowledged this in a handwritten report: "Now that I have been thinking about it, I estimate that the eyepiece of the sector we used for the observations of the obliquity of the ecliptic diverged from the plane of the instrument by more than 10 or 12 minutes... We were therefore wrong by about a minute in the distance of? - Orion at the zenith ... On the other hand, I could not close my eyes and ignore the divergence of the scale with respect to the plane of the meridian, which I knew approximately from the observations of the Sun». Cf. P. Bouguer, Remarques historiques et critiques sur les observations faites au Pérou de la distance de l'étoile d'Orion au zenith, Archives de l'Observatoire de Paris, ms. C-2-7, Fo. 4v.

27 Juan and Ulloa echoed these expectations in their writings (Observaciones..., pp. 271-2): «... its management was so satisfactory, accurate, firm and, that it made us observe unusual movement in the Stars ... We advised of this news to MM. Bouguer and La Condamine, who doubted it, seeking to attribute any fault to our instrument; they were satisfied by several observations, which they repeated with eyepieces fixed on the wall, where the movement of e-Orion was significantly observed》.

EMPIRIA. Revista de Metodología de Ciencias Sociales. N. ${ }^{o}$ 18, julio-diciembre, 2009, pp. 115-146. ISSN: $1139-5737$ 
cussions and, moreover, with very considerable reverberations in cosmological and philosophical terms ${ }^{28}$.

The observations they made, although the results were close to each other, still showed an irreducible degree of dispersion. Despite the great effort expended, in $1741 \mathrm{La}$ Condamine was obliged to acknowledge to Bouguer that, at least in his case, it had all been an illusion caused by the incidence of permanent personal errors of observation ${ }^{29}$. The stars were fixed and the dream of glory vanished. The conclusion was worrying, because if these were all personal errors, what guarantee did the expedition members have that they were able to work out the value of a degree? With this concern, they again began some observations that finally led them to a value whose average error we can now reckon at around $0,04 \%$, and which in absolute terms represented an oscillation of approximately 22 toises. An important figure, which did not bring the issue to a final conclusion. There was still uncertainty about the polar flattening of our planet which required some justification on the part of the expedition members. It was clear, then, that Newton was right, and it also proved that an unequivocal numerical conclusion was impossible ${ }^{30}$.

So the results were inconclusive with regard to the measurements of the planet. The difference between the axes was too small for the level of precision that could be achieved through empirical procedures.

However, the word failure was never mentioned. Their contribution to science was never questioned, since the expedition to Peru had made the most ambitious set of systematic observations ever taken up to that time. Reflection on their mistakes led to much debate, which was crucial in understanding the significance of science's shift from cabinet studies to field observations. Not only did no one speak of failure, but on the contrary, awareness of the difficulties led those involved in experimental work to seek more tools, more formulas and more observations, if it was indeed hoped to transform the Earth into a scientific subject that could be mobilized through books or maps. La Condamine, always the most astute of the expedition, seemed to sense it when he wrote that «the real and the intelligible are equally subject to mathematical demonstration». In its contact with instrumentation, in the process of the identification of errors, the

${ }^{28}$ It seemed that at last they were on the threshold of their journey into the history books; the design of a systematic monitoring program aimed at finding a stable law of variation was both exciting and necessary to complete the observations. The figures that they initially considered made a variation of up to a minute plausible; had their suspicions been confirmed, the finding would have catapulted them to glory.

${ }^{29}$ La Condamine acknowledged this in all humility to Bouguer in a letter (Quito, 3.VIII.1741): «I am tempted to attribute to my own errors the greater part of the errors», Bibliothèque National (París), Nouvelles acquisitions françaises, ms. 6197, Fo. 17r.

${ }^{30}$ La Condamine acknowledged it quite clearly and modestly: «But what is the degree of flattening, and in what ratio do degrees of latitude grow as they come closer to the poles? This is what we still do not know and what, perhaps, it is impossible to learn; at least without having a much higher number of degrees measured». Cf., La Condamine, (1746). P. 637.

EMPIRIA. Revista de Metodología de Ciencias Sociales. N. ${ }^{o}$ 18, julio-diciembre, 2009, pp. 115-146. ISSN: 1139-5737 
Earth had become an object which, as well as gravitating around the sun, was being tossed between two continents, by many disciplines and for many purposes. From the position of the atmospheric layers to the density of the strata of material, from the influence of the atmosphere on light or the mountains on gravity, all questions were to be asked and all symptoms to be interpreted. Half a century later, scientific instruments such as the barometer would remain effective for clarifying the new complexity of the territory and its vegetable or natural diversity. The question about the measurement of the meridian had converted Earth into a computable object.

Geodesy was born as a scientific discipline. From that moment on, maps would become a different thing. Before they were transformed into diplomatic documents, instruments of political negotiation and monuments to geometrical reason, it was necessary to discuss standards and agree ranges of accuracy. The expedition we discussed above was effectively a laboratory for the evaluation of the practices we now properly identify as geodesics. Maps, the new cartographic documents, evolved into instruments that broke the ties of territories with the cultures that sustained them and consequently enabled those territories to reach the offices of the administration as reliable representations of space. Everyone seemed excited about this tendency towards abstraction, and no one seemed to regret the disappearance of the traces of humanity. Geography was emancipated from history, because no one wanted to know the accounts of story-tellers, but only the accounts of bookkeepers: the figures that defined positions and made populations invisible.

\section{THE CREATION OF A DRUG}

When matters of health come into play, problems become dramatic. The longitude chronometer promised many improvements in the navigation of the Atlantic, and this explains its transformation into a strategic objective. Its promoters never tired of singing its praises, but in practice its use was never free of serious complications. In any case, these were potential errors that could be offset in many ways, and the analysis of which demanded impeccable training. In medicine, experiments are more expensive, and new developments must be checked with less margin of error. A modern state cannot be built (it cannot function) without ensuring the suitability of the remedies recommended. Here let us pause to consider a substance that for some time acted as a kind of panacea, a real symbol of the beneficial power of American nature: quinine, a febrifuge which fulfilled the longing for a botanical El Dorado. But to attribute properties to a substance is a task involving aspects of medicine, botany, chemistry, lawand even police, if you want to keep the quacks, charlatans, healers and tricksters out of the picture.

And in fact the promotion of a pharmaceutical involved the mobilization (or creation) of very considerable state resources. Nowadays we recognize the active 
principle of a medicine by its chemical composition. This process of de-naturalisation of knowledge, which divorces plants radically from their industrial or medical properties, seems to us quite normal. There was always a culture of therapeutic remedies, but during the eighteenth century great efforts were made to raise the status of practices whose efficacy nobody could guarantee, of substances whose makeup was concealed, not to mention production and distribution methods which nobody controlled. And, as we have said, from the eighteenth century onwards governing implied the production of instruments capable of pulling together the unconnected experiences of the plant collector, the pharmacist and the physician. Here, then, we are referring to the emergence of a new object, the pharmaceutical, which refined the vegetable world in an operation which consisted of dispensing with life to experiment with material.

Quinine began to circulate as a powerful febrifuge from 1639 onwards. However, it was not accepted internationally straight away, since French doctors only began to prescribe it in 1655, while the English did not include it in their Pharmacopoeia londinensis until 1677. By about 1711 agreement on its effectiveness appears to have been general, although the frequency of adulteration raised all sorts of different suspicions ${ }^{31}$. We know that in Europe it was distributed as a powder or as pieces of bark, which might contain mixtures of different species and which, of course, gave rise to considerable uncertainty given the possibility that its properties might have different degrees, and that different species might act in particular ways. Since this was the case, doctors did not know what they were prescribing, and nobody was in a position to establish strong links (that is, causality) between each variety of the plant and the active principle. Medical experience was not enough, since it was based on the administration of a product which arrived ready-packaged. It was therefore necessary to shift the location of the problem and to approach it as botanists, which meant discovering links between the structure of the plant and its curative properties.

This was not going to be easy, principally because since the end of the seventeenth century European culture had been living in a state of anxiety due to an excess of information which seemed impossible to cope with ${ }^{32}$.

In botany, for example, the number of known species increased fourfold between 1550 and 1700, which made the problems of communication a hundred times worse, due to the amalgam between classical and modern names which was then current (Stroup, 1990, pp. 70-71). The creation of nomenclatures to unify this vegetable tower of Babel was essential and, of course, the most urgent thing was to purge the language of any trace of tradition: to set free knowledge

31 See Jaramillo (1949) (offprint from the Revista de la Real Academia de Ciencias de Madrid); Guerra (1977), pp. 7-26; Lafuente \& Estrella (1986); Puig-Samper, (1991), pp 219-240; Estrella (1987), pp. 27-52.

${ }^{32}$ An anxiety which affected all areas of knowledge, and spurred on the creation of notebooks of selected readings, encyclopaedias and dictionaries, as shown by Richard Yeo (2001).

EMPIRIA. Revista de Metodología de Ciencias Sociales. N. ${ }^{\circ}$ 18, julio-diciembre, 2009, pp. 115-146. ISSN: 1139-5737 
from any sense of local roots. In this point Linnaeus's role was crucial ${ }^{33}$. It is not just that he imposed an efficient nomenclature and a less overwhelming taxonomy, drastically reducing the 698 genera recognized by Tournefort. His insistence on creating guidelines for memorisation was bound up with the production of pupils who would guarantee more standardised procedures than those common among plant collectors. These «apostles», the term by which Linnaeus knew them, knew that their work was fieldwork and always involved the description and drawing in situ of the object under study (Koerner, 1995, pp. 145$162,150-155)$. Botanical drawings thus acted as a tool to resolve the problem of identity. But their production was very expensive, especially when it was a matter of exotic plants, the knowledge of which had to cross oceans: that is, when they needed to be known at a distance, whether it was in Uppsala or Madrid that the relationship between names, properties and plants was to be calculated.

We shall not go into the alleged usefulness of this enormous undertaking of classification in which all empires became involved. Here we are interested in considering the method, which as we know consisted of encouraging the ability of the expedition members to detect the distinctive features on which the classi-

33 The introduction of the Linnaean system into Spain, although it had been superficially known for some years, came about in 1751 with the arrival in Madrid of one of Linnaeus's favourite disciples, Pehr Löfling, with a mission to study the flora and fauna of Iberia; although there has also been mention of another possible point of entry through the College of Surgeons of Cadiz, directed by Virgili. Cf. González (1990), pp. 381-95; Ryden (1957); Puig-Samper, Maldonado Lucena (1987), pp. 69-83; F. Pelayo (ed.) (1990). The institution which played the most decisive role for the development of Spanish botany and the introduction of the Linnaean system was the Royal Botanical Garden of Madrid. Although when the teaching of botany began in 1757, no texts were actually printed in the Botanical Garden of Madrid - then known as the Garden of Migas Calientes- the commentaries of Quer in his Flora Española (1762) give some idea of the method used. In this work, in which he insists on utilitarianism and practical observation, Quer claims that he is setting out the principles that he himself had studied following the system of Tournefort, «which is the easiest, clearest and most comprehensible of all». Puig-Samper (1987), pp. 59-78. An important step forward for the knowledge of Linnaean botany in Spain was taken by Miguel Barnades, who was appointed professor on the death of Quer in 1764, when he introduced the system of the Swedish academic, together with other more modern ones, in his book Principios de Botáni$c a$ (1767). Barnades acknowledged Linnaeus as the reformer of botanical nomenclature and as the Maestro par excellence of Plant science, and therefore recommended his Philosophia Botanica for the theoretical study of the subject and the Genera plantarum for practical knowledge. In addition to the strictly Linnaean system, Barnades introduced in his work comments on the work of Georg Christian Oeder, Professor of botany in the Royal Garden in Copenhagen, Elementa botanicae (Copenhagen, 1764-66), as well as on Michel Adanson, who according to Barnades continued the Fragments of a natural method of Linnaeus, and was a great reformer of the discipline through his Familles des plantes (Paris, 1763-64), in which he tried to distance himself from the artificial methods of classification. In spite of the introduction of Linnaeus's system in the work of Barnades, the final generalisation of the Linnaean system in Spain did not take place until a few years later. The death of Minuart, in 1768, and of Miguel Barnades, in 1771, left the positions Of Professor in the Royal Botanical Garden vacant until they were occupied by Casimiro Gómez Ortega (1772) and Antonio Palau Verdera (1773), both members of the Royal Academy of Medicine of Madrid. Colmeiro (1875).

EMPIRIA. Revista de Metodología de Ciencias Sociales. N. ${ }^{\circ}$ 18, julio-diciembre, 2009, pp. 115-146. ISSN: $1139-5737$ 
fication system was based, and to train them in the production of a type of highly codified drawing.

Very little was left to improvisation, for the draughtsman had to adapt himself to a plan which, for example, obliged him to show the upper and lower faces of leaves, and their arrangement on the stalk. As to flowers, a decisive factor in the Linnaean system, cross-sections had to be shown and, in the case of seeds, different stages of maturity. And this is how the botanists resolved the problem of communication, for the nexus between the Latin name and the technical image was the expression of a consensus which enabled them to uproot the plant from its native soil and move it to all corners of the earth ${ }^{34}$.

The scale of the problems grew if what was required was to transform a vegetable species into a medicine. The case of quinine is particularly interesting 35 . Not all quinine was equally effective as an antipyretic, and so somebody had to say something which would help to discriminate between the good (that is, the medicine) and the useless (that is, the placebo or fake). Many thought that its efficiency depended on the care with which the bark-cutters handled the goods ${ }^{36}$. But the botanists dispelled this and other unfounded beliefs. Anyone convinced of the one-to-one correspondence between species and properties would continually produce arguments against practical people, and however much they might swear that their knowledge was based on experience, they would only believe those who talked of experiments, showed drawings and labelled in Latin. This was the policy applied by the botanists Hipólito Ruiz and José Pavón (members of the expedition to Peru) in their arguments about the quinine of San-

${ }^{34}$ As to the works of Linnaean botany produced by the scientific expeditions to America and which were published, since the majority were not, we may single out those of Hipólito Ruiz and José Pavón, Florae Peruvianae, et Chilensis Prodomus,..(Madrid, Sancha, 1794), the Systema vegetabilium... (Madrid, G. Sancha, 1798) and Flora Peruviana, et chilensis, sive descriptiones et icones plantarum... (Madrid, G. Sancha, 1798-1802), where a great number of new botanical species were described for science.

35 In the seventeenth century quinine became an infallible remedy against the dreaded fevers, and thus the object of an important business for the Spanish crown. It is no wonder that many treatises were published, both from the botanical point of view and from the medical, which sought to discover new species and the characteristics and properties of those already known; or which introduced improvements in its dosage and possibilities. Two important defences for this product as early as the eighteenth century were the books of José Alsinet de Cortada, Nuevas utilidades de la Quina (Madrid: Antonio Muñoz del Valle, 1763), and that of José de Masdevall on the epidemic of Catalonia, in which he defends its almost exclusive use against tertian fevers. From a botanical point of view, we should mention the work of Hipólito Ruiz López (1752-1816) Quinología, o Tratado del Arbol de la Quina o Cascarilla (Madrid: Vda. e Hijo de Marín, 1792), to which we shall refer later. This work, in which he studies seven species of cinchona, met with great success, being much translated; and with it began a heated controversy with the school of José Celestino Mutis y Bosio (1731-1808), who held a different opinion on species and the value of their discovery. Mutis' point of view was published after his death in El arcano de la quina (Madrid: Ibarra, 1828). See, among the numerous publications relating to this subject, San Pío (1992); Frías (1992); Restrepo (1993), pp. 17-327.

36 Ruiz (1994) [facsimile edition of Madrid: Vda. e hijo de Marín, 1792], p. 18.

EMPIRIA. Revista de Metodología de Ciencias Sociales. N. ${ }^{o}$ 18, julio-diciembre, 2009, pp. 115-146. ISSN: $1139-5737$ 
ta Fe. For Ruiz and Pavón the only data to be considered as botanical were those obtained by means of the strict application of a methodology which would leave nothing to the improvisation of the draughtsman, and even less to the memory of the plant collector. Laboratory work was just as suspect as that carried out by collectors, for only the double condition of witness and expert could guarantee the correct channelling of local therapeutic practices into the realms of pharmacology $y^{37}$. Thus the function of the botanist was to translate forms into words, but also to translate local knowledge into technical language.

This is no small matter, especially if behind the project there was a metropolis seeking to administer the flora as part of its new wealth ${ }^{38}$. Establishing unambiguous terminology meant names could be correlated with properties; in other words, botany could be organized as a controlling body of floral resources, converting pharmacology into an interface directed towards therapeutic remedies. The problem facing us, just as it faced the botanists who were sent to the colonies, is how to establish a stable and recognizable link between the bark of some specific species of quinine and its condition as an antipyretic. Not all were equally effective and, of course, it was impossible to administer an empire if its qualities sometimes depended on taste, other times on feel, other times on colour etc. For this reason it was necessary to make use of chemical procedures, and to try to see in the composition of the residues left after boiling, distillation and/or combination with other substances some distinctive sign which would do away with ambiguity once and for all ${ }^{39}$. Chemical experiments, still at an early stage, were not decisive because they suffered similar problems of standardisation of names and instruments. Finally it was necessary to produce procedures for identifying the bark, to assist in the growing demand for quinine and its market. So they chose to combine the description of the husk of each species with that of the plant, trying to avoid the use of certain characteristics which had until then been frequent (such as the interior colour of the bark or its taste), or those very general features which might be shared with many other plants $^{40}$. Thus Hipólito Ruiz' Quinología was always seen as a treatise on American botany, but it can also be read as a manual of colonial policy (or police), teaching how to differentiate twelve different signs in the bark (surface, exterior

37 Ruiz, op. cit., prologue, unnumbered.

38 During this period the Europeans found some of the most important medicinal plants for the development of their pharmacopoeia, such as Cascarilla or Quinaquina (South America, 1670), Simaruba (Cayenne, 1713), Quassia (Guayana, 1714), Angostura (Venezuela, 1759), and Ratania (Peru, 1779). Also important was the discovery of Ipecacuana, which would be used against dysentery, and the advances in the medicinal and economic properties of Cinchona.

39 See the analyses that Ruiz requested from the chemist Pedro Gutierrez Bueno, then Professor of Chemistry in the Royal Laboratory of the Botanical Garden, in Ruiz, op. cit., pp. 96-96.

${ }^{40}$ See the systematic rejection of the features attributed by Zea to the bark of the orange cinchona, who considered them to be ambiguous, in Hipólito Ruiz and José Pavón, Suplemento a la Quinología. [s.1.]: Fundación de Ciencias de la Salud, 1994 [ Facsimile edition, Madrid: Vda. e Hijo de Marín, 1801], pp. 48-51.

EMPIRIA. Revista de Metodología de Ciencias Sociales. N. ${ }^{o}$ 18, julio-diciembre, 2009, pp. 115-146. ISSN: $1139-5737$ 
colour, interior colour, degree of curvature, thickness, fleshiness, weight, consistency, brittleness, resin, smell and taste) in order to avoid fraud.

Sometimes botany failed to resolve all the doubts about the virtues of the species, and it was necessary to turn to the physicians in order to ensure the transplantation of a plant and, in consequence, to turn a potion into a medicine. Let us look at the example of what happened in 1782 when Sebastián López Ruiz sent the first cinchonas from New Granada to the court in Madrid. In 1784 The Royal Apothecary Laboratory, the body responsible for controlling the market of spices and medicinal remedies, commissioned a study from 22 specialists. Four years later, at the request of Mutis, second tests were carried out in order to confirm the systematic adulteration of consignments, a practice which, as well as exhausting the forests of Loja by devastating the antipyretic species and those which had no such value whatsoever, could only be corrected by installing the control of quinine in Santa $\mathrm{Fe}^{41}$.

Passing rapidly over the political and tax problem, we may mention that the reports were just as contradictory as the interests which motivated their production, so that botanists of two different regions were unable to agree and to settle this colonial conflict. Obviously, however, it was not our intention to talk about botany, but about quinine and the procedures adopted to stabilise its traffic through pharmacological networks, or in other words scientific and metropolitan networks. Because what happened is that the Empire now knew how to manage this new type of wealth and conflict: by calling on the laws of botany and of the market, of academics and of tax collectors. And, as a last resort, if the conflict between the physicians and botanists persisted, or if perhaps it was scientists in Bogota who broke the consensus with those from Quito, then the Royal Apothecary Laboratory would have to reassert its authority by the use of transparency, by publishing the results obtained by the new experiments.

The difficulty of creating a pharmacological standard in no way detracts from the increased technical profile of the discussions on quinine. And it is by no means insignificant that the Royal Apothecary, the exclusive pharmacy that supplied the court of Madrid, was forced to reinvent itself in the late eighteenth century as a laboratory and tribunal rather than as a repository and registry. Of course, all four of these functions are connected with the problem of authentication, but what we want to highlight here is the difference in emphasis between proving with facts and proving with documents: a contrast that marks a before and an after. The growing importance of botanists and chemists is an innovation that strengthens the role of experts and their conventions in the management of public affairs.. It is also remarkable that the Royal Apothecary, unable to produce all the facts to enable it to provide a solution to the conflict, threatened the polemicists with transparency of information in order to ensure, firstly, its role as

${ }^{41}$ On the controversies about the cinchonas of Santa Fé, see Puig-Samper (1991), pp. 219-239. Among the most recent texts we may recommend the articles by Matthew James Crawford: Crawford (2007). Also Bleichmar (2007), pp. 225-252.

EMPIRIA. Revista de Metodología de Ciencias Sociales. N. ${ }^{\circ}$ 18, julio-diciembre, 2009, pp. 115-146. ISSN: $1139-5737$ 
mediator and/or regulator, and secondly the benefit which would arise from the public comparison of views between experts.

Developing a drug was a task that set in motion broad sectors of the colonial administration on both sides of the Atlantic, as well as an unprecedented constellation of scholars, judges and politicians. Finally, fixing the old problem inherited from quinine involved bringing together in a totally new way a myriad of small activities in very diverse areas, including the harvesting of the bark by Andean farmers, its handling and shipment by traders, its packaging and labelling by pharmacists, its study and classification by botanists, its analysis and quantification by chemists, and its legal regulation and taxation by administrators.. Together with this mixed bag of participants, it was also necessary to coordinate the different languages and traditions on which institutions as diverse as apothecaries, consulates, laboratories, courts, estates and hospitals based their authority. In short, what we are trying to say may be expressed in a few words: in practice, ensuring that something was a drug involved changing the world it sought to heal; initiating a way of doing things according to other values, other criteria and other standards, by way of new players and different institutions. No wonder, then, that their first attempts failed, and in practice the consolidation of new devices for computing and standardization would take Modern man over a century of struggle, against tough enemies, who they would depict as superstition, ignorance and intrusion: three attitudes that would be criminalized as anti-modern, antisocial, and uneconomic..

But there is no better example of this than the Catastro, or census and statistical investigation, of Ensenada ${ }^{42}$ to show the importance of the new links which were emerging between moral economy, procedural transparency, and new technology.

\section{THE ALGEBRA OF FAIRNESS}

Strange though it may seem, until the eighteenth century there was little support for the idea that the country could have dimensions; or that no image of it could be accurate if it did not include a census of everybody who lived in it, including criminals and paupers ${ }^{43}$. To include them all was to count heads, no

\footnotetext{
${ }^{42}$ In general, the information provided is based on the excellent work by Carmen Camarero Bullón (2002) «Vasallos y pueblos castellanos ante una averiguación más allá de lo fiscal: el Catastro de Ensenada, 1749-1756», pp. 113-387.

43 We should not forget the project of Pedro de Esquivel to create an Atlas of Spain, nor the questioning devised by Páez de Castro in 1559, nor the Royal Questionnaire of the Indies of 1573 and later topographical lists. As Abellán pointed out, the Questionnaire of 1573 contained the characteristics (official status, inscription of names, scope, responsibility, regularity, date and method) of what would later become modern statistics. However, it is worth pointing out that the information demanded was of a qualitative nature rather than quantitative, and that its main interest centres not only on geographical aspects but also on customs and history. Raquel Álvarez has indicated that the
}

EMPIRIA. Revista de Metodología de Ciencias Sociales. N. ${ }^{\circ}$ 18, julio-diciembre, 2009, pp. 115-146. ISSN: 1139-5737 
more, no less: a really strange concept, since cardinal numbers, unlike ordinals, do not link things with time and have no notion of origins. However, in order to mobilise wealth, the first thing to do is to be able to name it and then to count it. One simple example is enough to understand the importance of what was at stake, for many injustices were based on a system of taxation which was very sensitive to inherited privilege and blind to the most scandalous inequalities.

For the reform of the system, Ensenada had inherited two methods: millage (based on the declarations of the local authorities) and the catastro (based on declarations taken from the heads of households). The minister, in spite of the undeniably greater cost, opted for the second procedure. The Executive Order which was prepared described all the procedures for collecting, computing or recording data, and the different tables of relationships that could be built up from the data. The ultimate aim was to measure the wealth of the kingdom, an undertaking which at that time involved countable things; in other words, what should be counted and who should do the counting. Suddenly the kingdom was to become a mathematical object, like the dimensions of a ship, the shape of the planet or the ambient temperature.

The Order clearly set out times and activities: first a proclamation had to be issued announcing the start of the operation, giving a deadline for the heads of households to prepare their answers; then, after collecting the document, a tribunal was set up formed by the provincial governor (or his deputy), a notary, a clerk and a couple of scribes ${ }^{44}$. This part of the process concluded with the collection of the answers to the forty questions to which the 15,000 registered towns and villages had replied. Then began the hardest part, because it was necessary to check all the information collected, which meant that every item of land, goods, houses, individuals and claims of property had to be confirmed. What is amazing is the level of detail required: inventory in hand, they went round the territory, marking boundaries and taking notes of discrepancies. They also included omissions, a factor which led to the appearance of spaces which were not recorded in any document, and unexpected wealth ${ }^{45}$. At the end of the process there were two books: that of the locality, and the libro de raiz (source book), also known as the libro de lo real (real property register). And both

reduction of the initial questionnaire of 200 questions to a more functional one of only 50 (1577) meant, on the one hand, a distancing from the initial humanistic approach which would have characterized the first questionnaires and, on the other, the shift of the questionnaires towards the quest for «extensive basic knowledge, and not in-depth knowledge of a particular aspect of reality» (Alvarez, 1993, p. 187ss, 228).

44 At first the decree stated that an adviser, a geometer, a land surveyor, and a constable should also be present.

45 In the case of Gavia, after examination of 425 cases, the coincidence between lists and inspections was $25 \%$ (Camarero, 2002, p. 163). These results, as in the case of Jaén, where the count revealed 165.975 vines, 6.333 fig-trees, 27.133 fruit trees, 860 walnuts, 3.622 mulberries, 9.578 olive trees, 3.363 new olive trees «not yet in production», 135.769 holm oaks, 30.890 oaks, 138.633 pines and 15 yews, give an idea of the thoroughness of the process.

EMPIRIA. Revista de Metodología de Ciencias Sociales. N. ${ }^{\circ}$ 18, julio-diciembre, 2009, pp. 115-146. ISSN: 1139-5737 
documents were read out in their entirety in public, in case it was necessary to introduce any further rectifications, before going on to the preparation of the four different models of report (land, livestock, professional income and other goods ${ }^{46}$ ). Everyone will have his or her preferences as to the most important features of this undertaking. On this point we follow Bartolomé de Valencia, the brains behind the project, who wanted us to see it as a monstrous machine: in about 1752 he said «We need documentary proof to resist so much contradiction, hesitation and even mistrust, and not least by making it clear how this Monster is advancing in many provinces, in order to show the miraculous triumph over the impossible» ${ }^{47}$.

There was a trial period for the tax collection procedure (for the data that needed to be gathered before payment), as shown by the 22 pilot operations preceding the general mobilization, and which first introduced the principal innovations Among these was the need to introduce alphabetical listing of files, the obligatory public certification of reports, or the advisability of including the age of the censees or plans of their dwellings. It also confirmed the importance of writing total numbers out in long hand, or of demanding that local governors respect the procedure, without improvising information which was not called for, nor claiming false levels of accuracy ${ }^{48}$. But bureaucracy breeds bureaucracy, and there is no better proof of this than the 40,000 books of the real property register, including the original and the certified copy which was checked line by line, as well as the 1,849 volumes making up the 15,000 general replies and the 135,000 local reports. We are talking here about some forty million pages, produced between 1756-1759 and of about one hundred million arithmetical calculations ${ }^{49}$. There was a shortage of paper, for it was necessary to feed the voracious bureaucratic hunger of the scores of local governors, delegates, sub delegates or magistrates, since a great deal of support material (practical examples and models to follow) had to be prepared in order to train participants and standardise procedures.

And of course systems of control had to be put in place to guarantee the smooth performance of the work (Camarero, 2002, p. 234). It was all very new, but the appearance of accountancy offices is worthy of comment. In fact, the volume of work generated by the registry staff which had to be checked by specialist accountants was enormous. And it would have been very dangerous to wait until the end of the job to begin this audit. So, the checkers finally became the auditors of the registry process, which granted arithmetic a status hitherto unknown. There is little new that we can say about this fledgling body of mathe-

\footnotetext{
46 Also, for the laity, there was an additional fifth minor category showing taxes to be paid.

47 Quoted in Camarero (2002), p. 385.

48 See the case of Tagarabuena (Toro), in whose province the catastro cost 1,448,983.18 reales. Camarero (2002), pp. 177-178.

49 Camarero (2002), p. 371. In Burgos alone the number of pages copied in «source» books was 3.598.736.
} 
maticians ${ }^{50}$. Those who are more interested in political, military or economic history may indeed be grateful to us for reminding them that the study of the catastro of Ensenada is tantamount to observing the birth of the tools with which the state operates through its governors, armies or businesses. The literature on the subject is always quick to jump to conclusions and to say that without taxation or the Treasury there is no state. But that is not the question since, as Camarero Bullón has explained, the Public Treasury did not need such a reliable or exhaustive database in order to continue to function ${ }^{51}$.

Ensenada knew that the value of all this effort did not lie just in the notion of distributive justice, but in the way in which it had been done and in the consensus that it had engendered ${ }^{52}$ : as the minister said in his report to the King in April 1756: «The idea was not new, but perhaps Your Majesty will be the only sovereign to establish it with such formality and knowledge of your dominions, and with the justice of having occupied very many honourable servants in years of distress $»^{53}$. In fact, the suspicion that the world could be a better place was hardly new. Another question is that of converting justice into a matter of numbers for, as Ensenada repeated, «the Council is not unaware of the laments of all those subjects whose authority, skill or power allows them to live without paying, or paying less than they should, [...] but since this is the sickness which

${ }^{50}$ The flood of numerical data that authors such as Hacking attributed to the nineteenth century was anticipated in the Spanish case in the middle of the eighteenth. Contrary to what happened in the case of Prussia, which is analysed by this author, it is noteworthy that the statistics of the catastro, if they were not published, were at least public. There is no evidence, however, that the private production of statistics had any importance in our country. In any case, the work of Hacking is indispensable in order to understand the links between a social concept of language, the emergence of biopolitics and their dependence on disciplines as different as astronomy, engineering, statistics and medicine, the constructors of hazard, risk and normality. See Hacking (1990); also Brian (1994).

${ }^{51}$ The accuracy of the catastro was so remarkable that two years later the engineers planning the irrigation channel of the Jarama were amazed by the precision of the measurements of the registry. It seems that the surface area represented on the map of the irrigation scheme was 78,176 fanegas, while the surface area shown in the investigations of the catastro was of 71,806 fanegas (9\% less); and the difference arose because the catastro did not count two paths for the passage of migrating livestock (since their ownership was unknown), nor the land occupied by the centres of population (Camarero, 2002, pp. 382-3).

${ }^{52}$ His proposal coincides with, and exceeds, that of the work which flourished at the end of the century during the reign of Friedrich Wilhelm II in the hands of some amateurs who, at the beginning of the nineteenth century, were able to get the king to approve the foundation of an «office to collect and unify statistical tables coming from different departments and offices». Its purpose would be «the most complete possible collection of material relative to the Prussian State, for the power of the State is based in part on its territory and in part on its people...; one provides the raw material and the other, through capital and labour, transforms it... hence the compilation of data naturally corresponds to two separate main areas, one geographical and the other anthropological... the information-gathering task of these two agents, great though it may be, can only be used with difficulty unless we appoint a third agent [...] provided with the necessary ability and instruments to deal with political arithmetic in the most general sense of the word. This man will transform the material from the first two agents in such a way that it may be used immediately by the supreme administrators of the country» (quoted in Hacking, 1990, 57-59).

53 Quoted in Camarero (2002), p. 370.

EMPIRIA. Revista de Metodología de Ciencias Sociales. N. ${ }^{o}$ 18, julio-diciembre, 2009, pp. 115-146. ISSN: $1139-5737$ 
weakens and destroys the common good and the State, and which Your Majesty must correct wisely, justly and precisely, it is imperative that they be made aware of it and submit to reason» (Camarero, 2002). And the matter was clear: not only should wealth and justice be translated into figures which could be balanced, but the procedure must be public and published. The happiness of the public was in the hands of mathematicians; and all these protocols we have mentioned, as well as the procedures for gathering and checking information, including the glorification of the head of the household, the public reading of the information and the preparation of tables and summaries, launched new forms of sociability and different forms of management.

And here we reach the point we were aiming at: for the accountants and their operations of computation (accounts) and tabulation (charts) convert the kingdom into a mathematical object (different from that handled by geographers, astronomers and naturalists) which, among many other things, satisfied the condition of being a mobile, recognized, experimental, and stable object that could be run through offices, and which the new civil service would have to refine and turn into a common heritage.

\section{NEW VALUES, NEW HERITAGE}

Our aim has been to show the role of technology in the creation of new objects, which replace nature or the environment and which share various characteristics. One of these is mobility, for these objects acquire their greatest efficiency when they can be conveniently packaged, whether in the form of a map or chart, or within an algorithm or product. Mobility is impossible without uprooting, which means that it is necessary to smooth away from any knowledge all traces of local loyalty; and, as we have seen, these circumstances can only be achieved by applying tools or technologies which translate what is random into measurable parameters. Thus an observation would be no more than a translation from the ordinary language with which we name things, to the specialized idiom with which we extract it from nature and install it in reality. We have no wish to dwell any longer on an idea which by now should be clear.

And now, a further paragraph on the question of new values and new heritage. To produce reality is an emphatic expression of modernity, and to maintain it is a titanic undertaking forcing us to link technology and values. Here we have presented various processes, for we have seen how the design of a pharmaceutical sets in motion questions affecting what we see as proof, and which involve its means of production. We said right at the beginning that a discussion on the common good or distributive justice may end as a debate among astronomers, botanists or mathematicians. And this is fascinating, because what is at stake is not the image of the world, but our ability to measure, scale and manage it; in other words, to mobilize it in all possible ways and without pause: sometimes in an equation, sometimes on a plan. The point is that it can be contained in a list, in a test tube, or in a garden.

EMPIRIA. Revista de Metodología de Ciencias Sociales. N. ${ }^{o}$ 18, julio-diciembre, 2009, pp. 115-146. ISSN: 1139-5737 
Values, ultimately, also become something to be traded, for when a microscope, an almanac or a jar of quinine is moved, it leaves behind traditional cultures and the means of producing and reproducing authority. Instruments, then, not only produce evidence, but also principles and heritage. It is therefore not surprising that, beside the cabinets of minerals, machines and maps, there should also be an abundance of archives, dictionaries and encyclopaedias which form, rather than a record of the world, a handbook of instructions to understand it and subsequently modify it.

\section{BIBLIOGRAFÍA}

Alsinet de Cortada, José, (1763): Nuevas utilidades de la Quina, Madrid: Antonio Muñoz del Valle.

Alvarez Peláez, Raquel, (1993): La conquista de la naturaleza americana, Madrid: CSIC.

BAKER, Keith Michael \& REILL, Peter Hanns, eds., (2001): What's Left of Enlightenment? A Postmodern Question, Stanford University Press.

BenNeTt, John, (1989): «A vial of water or a wedge of glass», in D. Gooding, T. Pinch and S. Schaffer (eds.), The uses of the experiment. Studies in the Natural Sciences, Cambridge University Press.

BENSAUDE-VINCENT, Bernardette, (2000): L'opinion publique et la science. A chacun son ignorance, Paris: Sanofi-Synthélabo.

BleICHMAR, Daniela, (2007): «Atlantic Competitions: Botanical Trajectories in the Eighteenth-Century Spanish Empire», in James Delbourgo and Nicholas Dew, eds., Science and Empire in the Atlantic World, New York: Routledge. pp. 225-252.

Biagioli, Mario, (1994): Galileo, Courtier: The Practice of Science in the Culture of Absolutism, Chicago, University of Chicago Press.

BOUguer, Pierre, Remarques historiques et critiques sur les observations faites au Pérou de la distance de l'étoile d'Orion au zenith, Archives de l'Observatoire de Paris, ms. C-2-7.

BrIAN, Eric, (1994): La mesure de l'État. Administrateurs et géomètres au XVIIIe siècle, Paris: Éditions Albin Michel.

Camarero Bullón, Carmen, (2002): «Vasallos y pueblos castellanos ante una averiguación más allá de lo fiscal: el Catastro de Ensenada, 1749-1756» in El Catastro de Ensenada: magna averiguación fiscal para alivio de los Vasallos y mejor conocimiento de los Reinos, 1749-1756. Madrid: Ministerio de Hacienda-Dirección General del Catastro, pp. 113-387.

Colmeiro, M. (1875): Bosquejo histórico y estadístico del Jardín Botánico de Madrid, Madrid.

CoOTer, Rogerand \& Pumfrey, Stephen, (1994): «Separate Spheres and Public Places: Reflections on the History of Science Popularization and Science in Popular Culture», History of Science, 32, pp. 237-267.

CRAWFORD, Matthew James, (2007): «Para Desterrar las Dudas y Adulteraciones: Scientific Expertise and the Attempts to Make a Better Bark for the Royal Monopoly of Quina (1751-1790)», Journal of Spanish Cultural Studies 8:193-212.

DASTON, Lorraine, (1995): «The Moral Economy of Science», Osiris, 10: 3-24.

EMPIRIA. Revista de Metodología de Ciencias Sociales. N. ${ }^{o}$ 18, julio-diciembre, 2009, pp. 115-146. ISSN: 1139-5737 
DASTON, Lorraine, (1999): «The Moralized Objectivities of Science», in W. Carl and Lorraine Daston (ed.) Sonderdruck aus Wahrheit und Geschichte. Göttingen: Vandenhoek \& Ruprecht, pp. 78-100.

DAUMAS, Maurice, (1953): Les instruments scientifiques aux XVIIe et XVIIIe siècles, París.

Estrella, E. (1987): «Contribución al estudio de la obra quinológica de José Pavón», $A s$ clepio, 39 (1): 27-52.

FríAs, Marcelo, (1992): José Celestino Mutis y la Real Expedición Botánica del Nuevo Reino de Granada (1783-1808), Madrid, Universidad Complutense de Madrid.

Galison, Peter, (2003): Einstein's Clocks, Poincaré's Maps: Empires of Time, New York: Norton.

GLICK, Thomas F. (1989): «Imperio y decadencia científica en el siglo XVIII español e inglés: la provisión de instrumentos científicos», in José Luis Peset (coord.) Ciencia, vida y espacio en Iberoamérica. Vol. 3, Madrid: CSIC, pp. 49-65.

Golinski, Jean, (1992): Science as Public Culture. Chemistry and Enlightenment in Britain, Cambridge: Cambridge University Press.

GonZÁlez BuENo, Antonio, (1990): «Penetración y difusión de las teorías botánicas en la España Ilustrada», in J. Fernández and Ignacio González Tascón (eds.) Ciencia, Técnica y Estado en la España Ilustrada, Zaragoza: Ministerio de Educación y Ciencia, pp. 381-95.

GuERRA, Francisco, (1977): «El descubrimiento de la quina» in Medicina e Historia, 69: 7-26.

Guillén TATO, Julio, (1973): Los tenientes de navio Jorge Juan y Santacilia y Antonio de Ulloa de la Torre-Guiral y la medición del meridiano, Madrid, 1973.

HACKING, Ian, (1990): The Taming of Chance. Cambridge University Press.

JARAMILlO ARANGO, Jaime, (1949): Estudio crítico acerca de los hechos básicos en la historia de la quina. Madrid: C. Bermejo.

JuAn, Jorge \& UlloA, Antonio de, (1748): Relación histórica del Viage a la América Meridional, (Madrid), edition by José P. Merino Navarro and Miguel M. Rodriguez San Vicente.

KOERNER, Lisbet, (1995): «Carl Linnaeus in his time and place» in Nicholas Jardine, James A. Secord and Emma Spary (eds), Cultures of Natural History. Cambridge: Cambridge University Press, pp. 145-162.

Knorr-Cetina, Karin, (1999): Epistemic Cultures: How the Sciences Make Knowledge. Cambridge (Mass.)/London: Harvard University Press.

La CONDAMINE, Charles M. ' (1746): Extrait des operations Trigonométriques, et des observations Astromiques, faites pour la mesure des degrés du Meridien aux environs de l'Equateur, Memoires de l'Académie Royale des Sciences.

LAFUENTE, Antonio, (1983): Una ciencia para el estado: la expedición geodésica hispano-francesa al virreinato del Perú (1734-1743), Revista de Indias, 43, pp. 549629.

LAFUENTE, Antonio, (1992): «Institucionalización metropolitana de la ciencia española en el siglo XVIII», Ciencia colonial en América, A. Lafuente and José Sala Catalá, eds., Madrid: Alianza Ed., pp. 91-118.

LAFUENTE, Antonio, [s.a.: 1995]: «Retórica y experimentación en la polémica sobre la figura de la Tierra», in M. Losada and C. Varela (eds.) Actas del II Centenario de Don Antonio de Ulloa. Madrid: Escuela de Estudios Hispanoamericanos (CSIC)/Archivo General de Indias, p. 125-140. 
LAFuente, A. \& Delgado, Antonio, (1984): La geometrización de la Tierra.: observaciones y resultados de la expedición geodésica hispanofrancesa al virreinato del Perú (1735-1744). Madrid: CSIC.

LAFUENTE, A. \& ESTRElla, Edurdo, (1985): Scientific enterprise, academic adventure and drawing-room culture in the geodesic mission to Quito (1735-1755), XVII International Congress of History of Science, Berkeley.

LAFUENTE, A. \& Estrella, E. (1986): «La Condamine en la América meridional», in $L a$ Condamine. Viaje a la América meridional por el río de las Amazonas. Estudio sobre la quina, Barcelona, Alta Fulla/ Mundo Científico.

Lafuente, A. \& Mazuecos, Antonio, (1989): Los caballeros del punto fijo. Ciencia, política y aventura en la expedición geodésica hispanofrancesa al virreinato del Perú en el siglo XVIII. Barcelona: Serbal/CSIC.

LAFUente, A. \& PeSET, José Luis, (1981): «Política científica y espionaje industrial en los viajes de Jorge Juan y Antonio de Ulloa (1748-1751)», Melanges de la Casa de Velázquez, pp. 233-262.

LAfUeNte, A. \& Peset, J.L., (1982): «Las Academias militares y la inversión en ciencia en la España Ilustrada (1750-1760), Dynamis», pp. 193-209.

Lafuente, A. \& Peset, J.L., (1984): «La question de la figure de la Terre: l'agonie d'un débat scientifique au XVIII siècle», Revue d'Histoire des Sciences, pp. 235254.

LAFUENTE A. \& Pimentel, Juan, (2002): «La construcción de un espacio público para la ciencia: escrituras y escenarios en la Ilustración española», in José L. Peset Reig (ed.), Historia de la ciencia y de la técnica en la Corona de Castilla, vol. IV, Salamanca: Junta de Castilla y León, pp. 111-155.

LAFUENTE, A. \& PUIG-SAMPER, Miguel A., et al., (1996): «Literatura científica moderna», in Historia literaria de España en el siglo XVIII, Francisco Aguilar Piñal (ed.), Madrid: Ed. Trotta/CSIC, pp. 965-1028.

LAFuente A. \& Sellés, Manuel, (1988): El Observatorio de Cádiz (1763-1831), Madrid: Ministerio de Defensa.

LAFUente, Antonio \& VAlverde, Nuria, (2004): «Linnaean Botany and Spanish Imperial Biopolitics», in Londa Schiebinger \& Claudia Swan, eds., Colonial Botany. Science, Commerce, and Politics in the Early Modern World, Philadelphia: University of Pennsylvania Press.

LATour, Bruno, (1993): We have never been modern, Cambridge Mass., Harvard University Press.

LeSen y Moreno, José, (1863): Historia de la Sociedad Económica de Amigos del País de Madrid. Escrita con autorización de la misma y en vista de los datos que existen en su archivo y biblioteca. Madrid: Imprenta del Colegio de Sordo-mudos y de Ciegos.

Licoppe, Christian, (1996): La formation de la practique scientifique. Le discours de l'expérience en France et en Angleterre (1630-1820). Paris: La Découverte.

DE LuC, J.A., Recherches sur les Modifications de l'Atmosphère (Geneva, 1749).

Middleton, W.E. Knowles, (1964): The History of the Barometer. Baltimore: Johns Hopkins Press.

Molina Martinez, M., (1992): Estudio preliminar to the facsimile edition of A. de Ulloa, Noticias americanas, Granada, Universidad de Granada.

Moral Roncal, Antonio Manuel, (1998): Gremios e Ilustración en Madrid (17751836). Madrid: Actas ed.

EMPIRIA. Revista de Metodología de Ciencias Sociales. N. ${ }^{\circ}$ 18, julio-diciembre, 2009, pp. 115-146. ISSN: 1139-5737 
PARK, Katharine, (2000): Una historia de la admiración y del prodigio», in A. Lafuente and J. Moscoso (eds.), Monstruos y seres imaginarios en la Biblioteca Nacional. Madrid: Biblioteca Nacional, pp. 77-89.

PARK, Katharine \& DASTON, Lorraine, (1998): Wonders and the Order of Nature. New York: Zone Books.

Pimentel, Juan, (1998): La física de la Monarquía. Ciencia y política en el pensamiento colonial de Malaspina, Madrid: Doce Calles, 1998.

PORTER, Theodore, (1995): Trust in Numbers. The Pursuit of Objectivity in Science and Public Life. Princeton: Princeton University Press.

Pelayo, Francisco (ed.), (1990): Pehr Löfling y la expedición al Orinoco, 1754-1761, Madrid: Quinto Centenario.

Puig-SAMPER, Miguel Angel, (1987): «La enseñanza de la botánica en la España Ilustrada: El Jardín Botánico de Madrid», in B. Sánchez, M.A. Puig-Samper and J. de la Sota (eds.), La Real Expedición Botánica a Nueva España, Madrid: Quinto Centenario, pp. 59-78.

PUIG-SAMPER, M.A., (1991): «El oro amargo. La protección de los quinares americanos y los proyectos de estanco de la quina en Nueva Granada», in M. Lucena Girardo, El Bosque ilustrado, Madrid, Icona, pp. 219-240.

Puig-SAMPER, M.A., MALdONADO, L. and LucEna, M., (1987): «Loefling y la Botánica española. La expedición al Orinoco (1754- 1761)», Asclepio, 39: 69-83.

Ramos Pérez, J. (1985): Las Noticias secretas de América de Jorge Juan y Antonio de Ulloa (1735-1745), Madrid, CSIC.

RESTREPO, Olga, (1993): «Naturalistas, Saber y Sociedad en Colombia», in E. Quevedo (ed.), Historia social de la ciencia en Colombia, 9 vols., Bogotá: Colciencias, Vol. III, pp. 17-327.

RoussEAU, Georges, (1990): «Los libros científicos y sus lectores en el siglo XVIII», in Javier Ordoñez and Alberto Elena, eds., La ciencia y su público: perspectivas históricas, Madrid: CSIC, pp. 147-224.

RuIz LóPEZ, Hipólito, (1792): Quinología, o Tratado del Arbol de la Quina o Cascarilla, Madrid: Vda. e Hijo de Marín.

Ruz, Hipólito \& Pavón, José (1994): Suplemento a la Quinología. [s.1.]: Fundación de Ciencias de la Salud [ Facsimile edition, Madrid: Vda. e Hijo de Marín, 1801], p. 48-51.

Ryden, S., (1957): Pedro Löfling en Venezuela (1754-1756), Madrid: Insula.

SAn Pío Aladren, Pilar (ed.), (1992): Mutis y la Real Expedición Botánica del Nuevo Reyno de Granada, 2 vols., Barcelona: Lunwerg/Villegas.

SCHAFFER, Simon, (1989): «Glass Works: Newton's Prisms and the Uses of Experiment», in David Gooding, Trevor Pinch and Simon Schaffer, eds., The uses of experiment. Studies in the Natural Sciences, Cambridge University Press, pp. 67-105.

SECORD, Anne, (2002): «Botany on a Plate. Pleasures and the Power of Pictures in Promoting Early Nineteenth-Century Scientific Knowledge», in Isis, 93, pp. 28-57.

Shapin, Steven \& Schaffer, Simon, (1985): Leviathan and the Air-Pump. Hobbes, Boyle and the Experimental life, Princeton University Press, New Jersey.

SHEET-Pyenson, Susa, (1988): Cathedrals of science: the development of colonial natural history museums during the late nineteenth century. Kingston Montreal: McGillQueen's University.

StewART, Larry, (1992): The Rise of Public Science. Rhetoric, Technology, and Natural Philosophy in Newtonian Britain, 1660-1750, Cambridge: Cambridge University Press.

EMPIRIA. Revista de Metodología de Ciencias Sociales. N. ${ }^{\circ}$ 18, julio-diciembre, 2009, pp. 115-146. ISSN: 1139-5737 
Stroup, Alice, (1990): A Company of Scientists. Botany, Patronage, and Community at the Seventeenth-Century Parisian Royal Academy of Sciences, Berkeley/Los Angeles/Oxford: University of California Press.

Trystram, F., (1979): Le procès des étoiles, Paris, Seghers, 1979.

TURNER, A., (1987): Early Scientific Instruments. Europe 1400-1800, London, Sotheby's Publications.

Turner, G.L'E., (1976): The London Trade in Scientific Instruments-Making in the Eighteenth Century, Vistas in Astronomy, 20, 173-182.

TURNER, G.L'E., (1990): Scientific Instruments and Experimental Philosophy 15501850, Hampshire, Variorum.

VALVERDE. Nuria, (2007): Actos de precisión. Instrumentos científicos, opinión pública y economía moral en la Ilustración española, Madrid: CSIC.

Valverde, Nuria \& Lafuente, A., (2009): «Space Production and Spanish Imperial Geopolitics», in Daniela Bleichmar, Paula de Vos, Kristin Huffine \& Kevin Sheeham, Science in the Spanish and Portuguese Empires, Stanford: Stanford University Press, pp. 198-215.

Yeo, Richard, (2001): Encyclopaedic visions: Scientific Dictionaries and Enlightenment Culture. Cambridge: Cambridge University Press.

ZúNígA, N. (1977): La expedición científica de Francia del siglo XVIII en la Presidencia de Quito, Quito.

\section{RESUMEN}

El artículo explora la forma en que la ciencia se convirtió en una herramienta para la racionalización de la monarquía, es decir, del gobierno de la gente y de sus territorios. Analizaremos cómo la tierra fue transformada en un artefacto geodésico medible, cómo fue tratada una planta para ser considerada un medicamente confiable, y cómo la noción de frontera entre países se desplegó en un sistema algebraico de contabilidad. Nadie como los científicos había soñado tanto con disciplinas, instrumentos y fórmulas. Y tampoco nadie había mostrado una pasión tan incontenible por traducir todos los problemas a síntomas, signos y números. Y así fue como el estado se convirtió en una cuestión científica y la ciencia en un problema de estado.

\section{PALABRAS CLAVE}

Objetos científicos, Ilustración, valores científicos, instrumentos científicos

\section{ABSTRACT}

This paper explores how science became a toolbox for the rationalisation of the monarchy: that is, of the government of the people and of its territories. We will analize how the Earth was transformed in a mensurable, geodesic artefact; 
how a plant was managed in order to be considered a reliable medicament; and how the notion of patriotic bound was deployed into an algebraic system for accountancy. Nobody like the scientists had dreamt so much of disciplines, instruments and formulas. Nor had anybody shown such an overwhelming passion for translating all problems into symptoms, signs and numbers. And so it was that the state became a scientific question, and science became a matter of state.

\section{KEY WORDS}

Scientific_objects, Enlightenment, scientific_values, scientific_instruments 